University of New Hampshire

University of New Hampshire Scholars' Repository

Natural Resources and the Environment

Scholarship

Natural Resources and the Environment

$7-1-2020$

\title{
New England Food Policy Council Survey Results
}

Cathryn A. Porter

University of New Hampshire, Casey.Porter@unh.edu

Catherine M. Ashcraft

University of New Hampshire, catherine.ashcraft@unh.edu

Follow this and additional works at: https://scholars.unh.edu/nren_facpub

\section{Recommended Citation}

Porter, Cathryn A. and Ashcraft, Catherine M., "New England Food Policy Council Survey Results" (2020). Natural Resources and the Environment Scholarship. 142.

https://scholars.unh.edu/nren_facpub/142

This Data Set is brought to you for free and open access by the Natural Resources and the Environment at University of New Hampshire Scholars' Repository. It has been accepted for inclusion in Natural Resources and the Environment Scholarship by an authorized administrator of University of New Hampshire Scholars' Repository. For more information, please contact Scholarly.Communication@unh.edu. 


\section{New England Food Policy Council Survey Report}

Cathryn A. Porter, University of New Hampshire (corresponding author)

Catherine M. Ashcraft, University of New Hampshire

\section{Introduction}

Little is known about food policy councils (FPCs) in New England, including their policy priorities and how they engage the public. This document provides the results of a survey of New England FPCs engaged in policy initiatives in New England conducted during October - December 2017 to understand FPCs' policy priorities, learn about the types of policy and planning processes the councils have recently led, and learn about how public participation was incorporated into these processes. The survey instrument is available at: https://dx.doi.org/10.34051/c/2020.4 (Porter and Ashcraft, 2020). This report also includes results from selected 2016 survey data provided by the Johns Hopkins Center for a Livable Future (CLF), an annual survey of all FPCs in the U.S. and Canada.

\section{Methods}

We identified 29 FPCs or networks in New England: 26 FPCs and two food policy networks were identified using CLF's 2016 survey data and one more food policy network was identified through an internet search. We recruited one representative from each of the 29 FPCs or networks to respond to a mix of open and closed-ended survey questions. The survey was conducted online through Qualtrics. To participate in the survey respondents had to (1) have been a member of the FPC for at least a year, and (2) report that the FPC was engaged in policy efforts. The University of New Hampshire Institutional Review Board for the Protection of Human Subjects in Research approved this study (IRB: 6761, approved 9/20/2017).

\section{Survey Results}

Out of the 29 New England FPCs or networks contacted, 18 completed the survey (Table 1). Researchers attempted to contact the 11 FPCs or networks that did not respond with follow up emails and phone calls. Five additional FPCs that did not complete the survey provided some information about policy priorities by telephone or email. Six FPCs did not respond to the survey and could not be reached by phone or email. Information about their policy priorities was determined through internet research. Based on the combined results, we determined that none of the three food policy networks were both active and engaged in policy efforts and 15 of the 26 FPCs were both active and engaged in policy efforts. 12 of the 15 FPCs actively engaged in policy efforts responded to the survey. 
Table 1. New England FPC and networks survey population, recruitment methods, and response rates

\begin{tabular}{|l|l|l|l|l|}
\hline Recruitment method & $\begin{array}{l}\text { Total \# } \\
\text { FPCs }\end{array}$ & $\begin{array}{l}\text { FPCs engaged } \\
\text { in policy }\end{array}$ & $\begin{array}{l}\text { FPCs not engaged } \\
\text { in policy }\end{array}$ & $\begin{array}{l}\text { Inactive } \\
\text { FPCs }\end{array}$ \\
\hline Responded to survey & 18 & 12 & 4 & 2 \\
\hline $\begin{array}{l}\text { Contacted by } \\
\text { telephone or email }\end{array}$ & 5 & 2 & 3 & 0 \\
\hline Internet research only & 6 & 1 & 4 & 1 \\
\hline Total \# FPCs & 29 & 15 & 11 & 3 \\
\hline
\end{tabular}

This survey focused only on food policy councils engaged in policy efforts. Table 2 presents an overview of the attributes of the 12 surveyed New England FPCs engaged in policy efforts.

Table 2. Attributes of surveyed New England FPCs engaged in policy

\begin{tabular}{|l|l|l|l|l|l|}
\hline $\begin{array}{l}\text { Name of food policy } \\
\text { council }\end{array}$ & State & $\begin{array}{l}\text { Geographic } \\
\text { scale }\end{array}$ & $\begin{array}{l}\text { Organization } \\
\text { type }\end{array}$ & Staff capacity & Budget \\
\hline $\begin{array}{l}\text { Bridgeport Food Policy } \\
\text { Council }\end{array}$ & CT & Municipal & $\begin{array}{l}\text { Embedded in } \\
\text { government }\end{array}$ & $\begin{array}{l}\text { Part-time paid } \\
\text { staff member }\end{array}$ & $\$ 0-10,000$ \\
\hline $\begin{array}{l}\text { Hartford Advisory } \\
\text { Commission on Food }\end{array}$ & CT & Municipal & $\begin{array}{l}\text { Embedded in } \\
\text { government }\end{array}$ & $\begin{array}{l}\text { Part-time paid } \\
\text { staff member }\end{array}$ & $\$ 10,000-25,000$ \\
\hline $\begin{array}{l}\text { New Haven Food Policy } \\
\text { Council }\end{array}$ & CT & Municipal & $\begin{array}{l}\text { Embedded in } \\
\text { government }\end{array}$ & $\begin{array}{l}\text { Part-time paid } \\
\text { staff member }\end{array}$ & No data \\
\hline $\begin{array}{l}\text { Cambridge Food \& } \\
\text { Fitness Food Policy } \\
\text { Council }\end{array}$ & MA & Municipal & $\begin{array}{l}\text { Embedded in } \\
\text { government }\end{array}$ & No data & No data \\
\hline
\end{tabular}




\begin{tabular}{|c|c|c|c|c|c|}
\hline $\begin{array}{l}\text { Massachusetts Food } \\
\text { Policy Council }\end{array}$ & MA & State & $\begin{array}{l}\text { Embedded in } \\
\text { government }\end{array}$ & $\begin{array}{l}\text { Part-time paid } \\
\text { staff member }\end{array}$ & $\$ 0-10,000$ \\
\hline $\begin{array}{l}\text { Worcester Food Policy } \\
\text { Council }\end{array}$ & MA & Municipal & Non-profit & $\begin{array}{l}\text { Full-time paid } \\
\text { staff member }\end{array}$ & $\begin{array}{l}\$ 25,000- \\
100,000\end{array}$ \\
\hline $\begin{array}{l}\text { Community Food } \\
\text { Matters }\end{array}$ & $\mathrm{ME}$ & County & $\begin{array}{l}\text { Grassroots } \\
\text { coalition }\end{array}$ & $\begin{array}{l}\text { More than one } \\
\text { paid staff } \\
\text { member }\end{array}$ & $\$ 0-10,000$ \\
\hline $\begin{array}{l}\text { Cumberland County } \\
\text { Food Security Council }\end{array}$ & $\mathrm{ME}$ & County & $\begin{array}{l}\text { Housed in } \\
\text { another non- } \\
\text { profit }\end{array}$ & $\begin{array}{l}\text { More than one } \\
\text { paid staff } \\
\text { member }\end{array}$ & No data \\
\hline $\begin{array}{l}\text { Good Food Council of } \\
\text { Lewiston-Auburn }\end{array}$ & $\mathrm{ME}$ & Municipal & $\begin{array}{l}\text { Grassroots } \\
\text { coalition }\end{array}$ & $\begin{array}{l}\text { Part-time paid } \\
\text { staff member }\end{array}$ & $\$ 0-10,000$ \\
\hline Healthy Waterville & $\mathrm{ME}$ & Municipal & $\begin{array}{l}\text { Grassroots } \\
\text { coalition }\end{array}$ & $\begin{array}{l}\text { Full-time paid } \\
\text { staff member }\end{array}$ & $\begin{array}{l}\$ 25,000- \\
100,000\end{array}$ \\
\hline $\begin{array}{l}\text { Washington County } \\
\text { Community Food } \\
\text { Council }\end{array}$ & $\mathrm{ME}$ & County & $\begin{array}{l}\text { Housed in } \\
\text { another non- } \\
\text { profit }\end{array}$ & No data & $\$ 0-10,000$ \\
\hline $\begin{array}{l}\text { Rhode Island Food } \\
\text { Policy Council }\end{array}$ & RI & State & $\begin{array}{l}\text { Housed in } \\
\text { another non- } \\
\text { profit }\end{array}$ & $\begin{array}{l}\text { More than one } \\
\text { paid staff } \\
\text { member }\end{array}$ & No data \\
\hline
\end{tabular}

Data source for analysis: Johns Hopkins Center for a Livable Future Food Policy Network 2016 survey data (Sussman and Bassarab, 2016).

\section{Policy Priorities and Policy Efforts}

The survey asked respondents to select their FPC's top policy priorities from a list of 13 policy priorities or write in additional options. Respondents most commonly identified food access as a policy priority (Figure 1). Other common policy priorities include: public health, food waste/recovery, land use/planning, economic development, and food justice/equity. 
Figure 1. Policy priorities of surveyed New England FPCs.

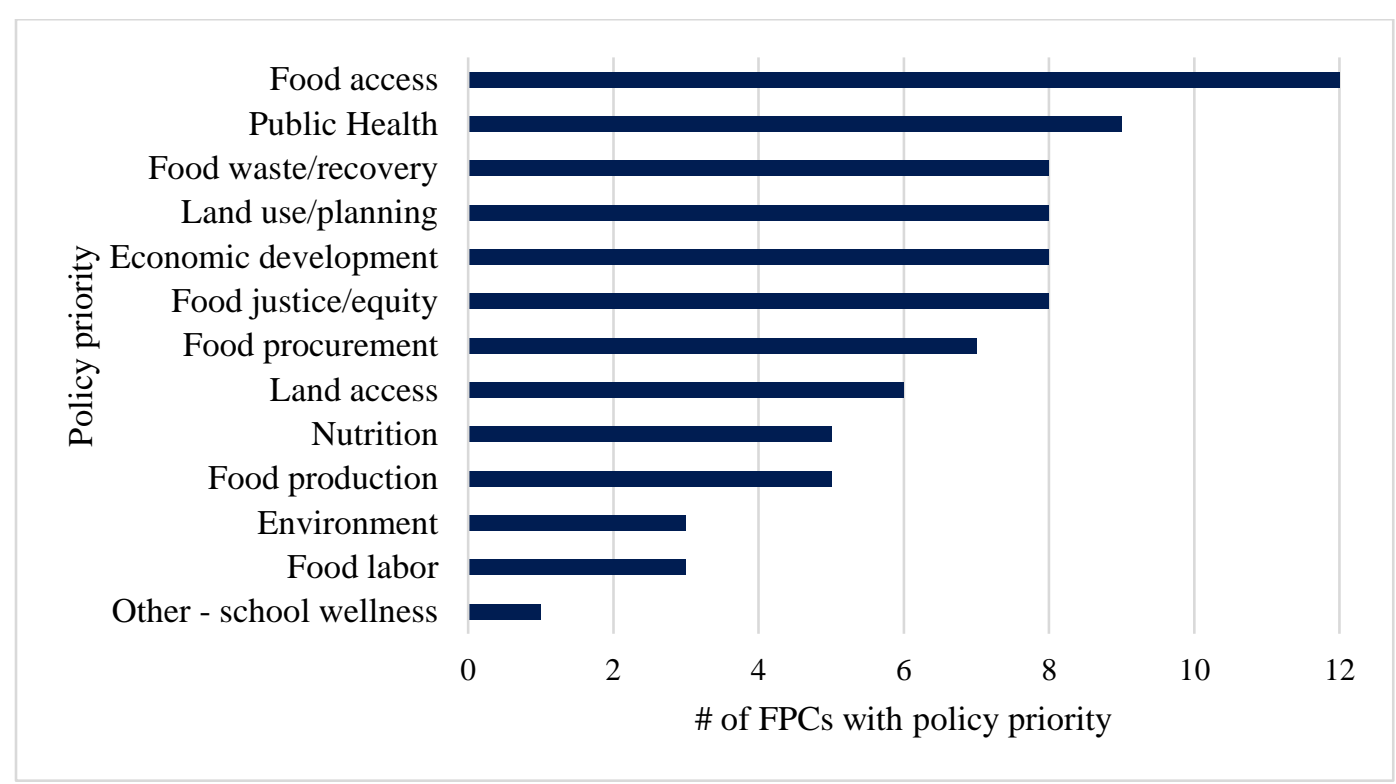

The survey asked respondents to identify up to three of their FPC's policy efforts, shown in Table 3. Common topics for FPC policy work that respondents identified include general food systems work, school food, and urban agriculture. Not all FPCs reported three separate policy efforts - one FPC reported two, and another reported only one policy effort.

Table 3. Policy efforts reported by surveyed New England FPCs.

\begin{tabular}{|l|l|}
\hline Urban agriculture & Increase summer meals provision and utilization \\
\hline Urban agriculture zoning ordinance & School wellness policy \\
\hline $\begin{array}{l}\text { Favorable zoning changes for agriculture, poultry } \\
\text { and bees }\end{array}$ & SNAP matching collaboration \\
\hline Urban agriculture master plan & SNAP Ed and Double Dollars at local markets \\
\hline City's Climate Action Plan & SNAP incentives at Farmers Markets \\
\hline Local Food Action Plan & Food access \\
\hline Community Food Charter & $\begin{array}{l}\text { Mitigating hunger/food insecurity through } \\
\text { advocating for program implementation }\end{array}$ \\
\hline State food strategy & Streamlining the emergency food system \\
\hline Strategic action plan & Permitting and licensing of new food businesses \\
\hline Action Plan Priorities & Protecting food workers \\
\hline Action Plan Topics & Food System Summit \\
\hline Community Food Assessment & Food Policy Forum \\
\hline Community Food Assessment & Wasted Food Policy Change \\
\hline School food security assessment & Equity Based Policy Change \\
\hline Cultural considerations in school food & Distribution infrastructure \\
\hline K-12 School Food Procurement & Processing infrastructure \\
\hline
\end{tabular}




\section{Workgroups}

Survey respondents identified the focus of workgroups of surveyed New England FPCs engaged in policy (Figure 2). Most New England FPCs engaged in policy (10) report having targeted workgroups.

Workgroups allow a council to take on multiple foci, and also provide a forum to engage members of the public who do not necessarily want to be a member of the council or can't commit the time to full membership. Three surveyed New England FPCs reported having a workgroup focused specifically on policy. Themes included within the "other" category include communications, food waste, cooperative procurement, recruitment committee, lead team, transportation, and planning and development.

Figure 2. Workgroups of surveyed New England FPCs engaged in policy.

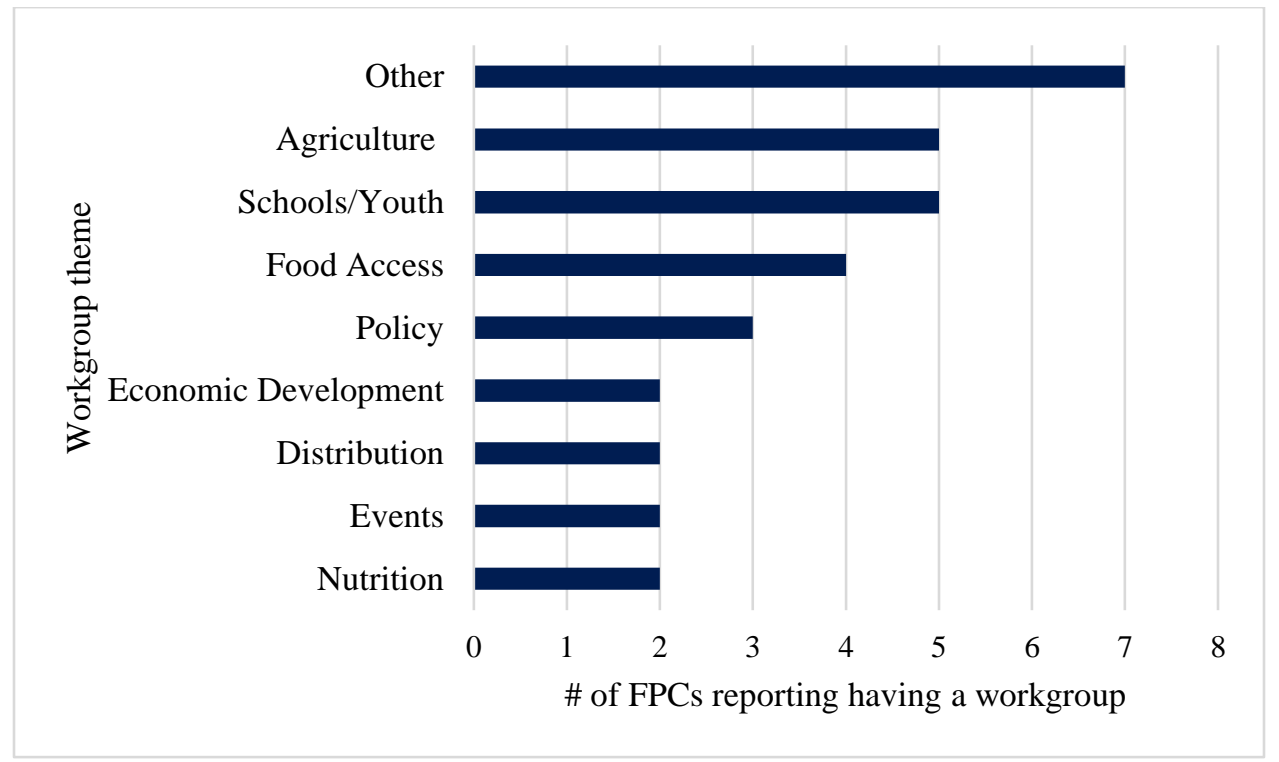

\section{FPC Membership}

Survey respondents identified the sectors and stakeholder groups currently represented as members of the FPC (Figure 3). A list of sectors and stakeholder groups was provided, and respondents could check all that applied or write in others. The membership of most New England FPCs is diverse. Well represented sectors in New England FPCs include food access, public health, government, farmers, nutrition, concerned citizens, and economic development. Sectors respondents wrote in under "Other" include researchers, legal aid, social justice, funder, small business, cooperatives, and emergency food providers. Fewer surveyed New England FPCs report having representatives from colleges and universities, food waste, food distribution, food processing, Extension or the fisheries sector as members. Most surveyed New England FPCs report their council membership includes individuals representing diverse genders, 
ages, income levels. Fewer, but still more than half of New England FPCs report having members representing diverse racial and ethnic backgrounds.

Figure 3. Membership of New England FPCs engaged in policy by sector and stakeholder group.

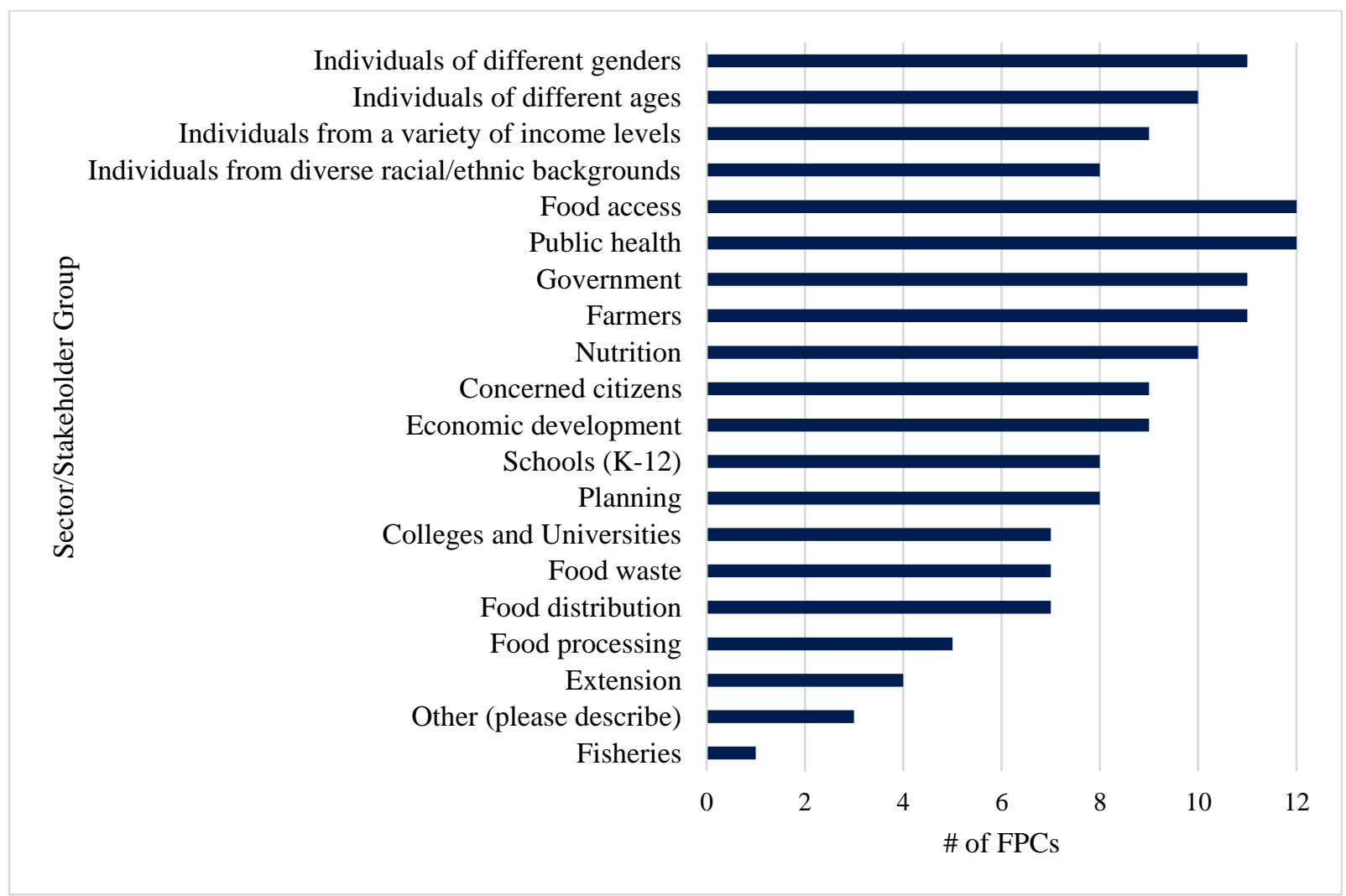

Fewer than half (5) of surveyed New England FPCs reserve membership seats (Table 4). Four FPCs reserve seats for community members or the public. Other common sectors for which seats are reserved are city government (two), food distribution (two), food access/hunger (two), agriculture/farmers (two), and nutrition/dieticians (two). No surveyed New England FPCs report reserving seats for groups representing diverse age, gender, income level or race/ethnicity. 
Table 4. Membership Seats Reserved by surveyed New England FPCs engaged in policy efforts.

\begin{tabular}{|l|l|}
\hline Council & Seats reserved for sectors/stakeholders \\
\hline$\# \mathbf{1}$ & residents, city officials \\
\hline $\mathbf{Z}$ & city departments, non-profit organizations, community members \\
\hline $\mathbf{3}$ & $\begin{array}{l}\text { city manager, hunger, processing \& distribution, food industry, consumers, dieticians, } \\
\text { city administration, public \& private nonprofit food providers, public }\end{array}$ \\
\hline$\# \mathbf{4}$ & $\begin{array}{l}\text { member of state senate, member of state house of representatives, commissioner of } \\
\text { agricultural resources, commissioner of public health, commissioner of elementary and } \\
\text { secondary education, commissioner of environmental protection, commissioner of } \\
\text { transitional assistance, secretary of housing and economic development, farmer or } \\
\text { representative of a farm organization, representative of food distribution, processing } \\
\text { and marketing interests, representative of direct-to-consumer marketing efforts, } \\
\text { representative of a local health department addressing food safety \& nutrition, food } \\
\text { safety expert, food processing \& handling expert, representative of community-based } \\
\text { efforts addressing nutrition \& public health. }\end{array}$ \\
\hline h5 & $\begin{array}{l}\text { hunger relief, nutrition, businesses in the food sector, farming, institutional food } \\
\text { management, public. }\end{array}$ \\
\hline
\end{tabular}

The survey asked respondents whether their FPC recruits members from diverse demographics (Figure 4). Respondents could select among provided options or write in additional options. Respondents from more than half of the surveyed FPCs report their FPC recruits members from under-represented groups. One council does not report recruiting from any of the listed demographic groups (age, gender, income level, race and ethnicity), and respondents from three councils reported being unsure of their FPC's recruitment strategy. No councils report specifically recruiting individuals of different genders. Four respondents report their FPC recruits members of diverse ages and diverse racial/ethnic backgrounds. Two report recruiting members representing diverse incomes. Other responses included recruiting individuals experiencing food insecurity, newcomers to the state, and recruiting youth to participate in a youth engagement group. 
Figure 4. Surveyed New England FPCs recruitment of under-represented groups.

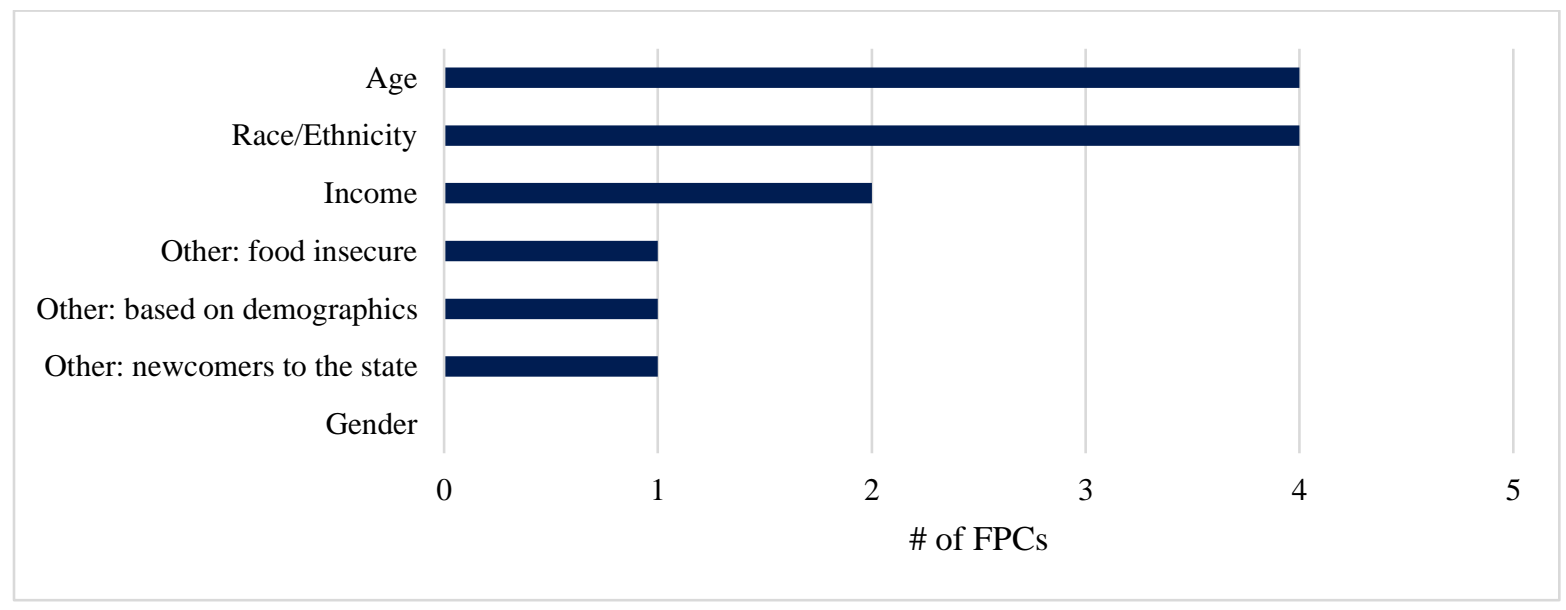

\section{Public Participation}

Survey respondents were asked to identify how they engaged the public through the policy efforts they identified, which are shown in Table 3. All surveyed New England FPCs reported engaging the public as part of at least one of their policy efforts (Figure 5). All surveyed New England FPCs report using multiple public participation methods, including strategies with more dialogue and strategies with lower levels of engagement. All but one New England FPC reported using at least three different methods to engage the public during a policy effort. The most commonly reported strategies are attending meetings of other organizations or groups, listening sessions or face-to-face discussions, and conducting interviews. Only two surveyed FPCs report not engaging the public for all identified policy efforts.

Figure 5. Public participation methods used by surveyed New England FPCs engaged in policy efforts.

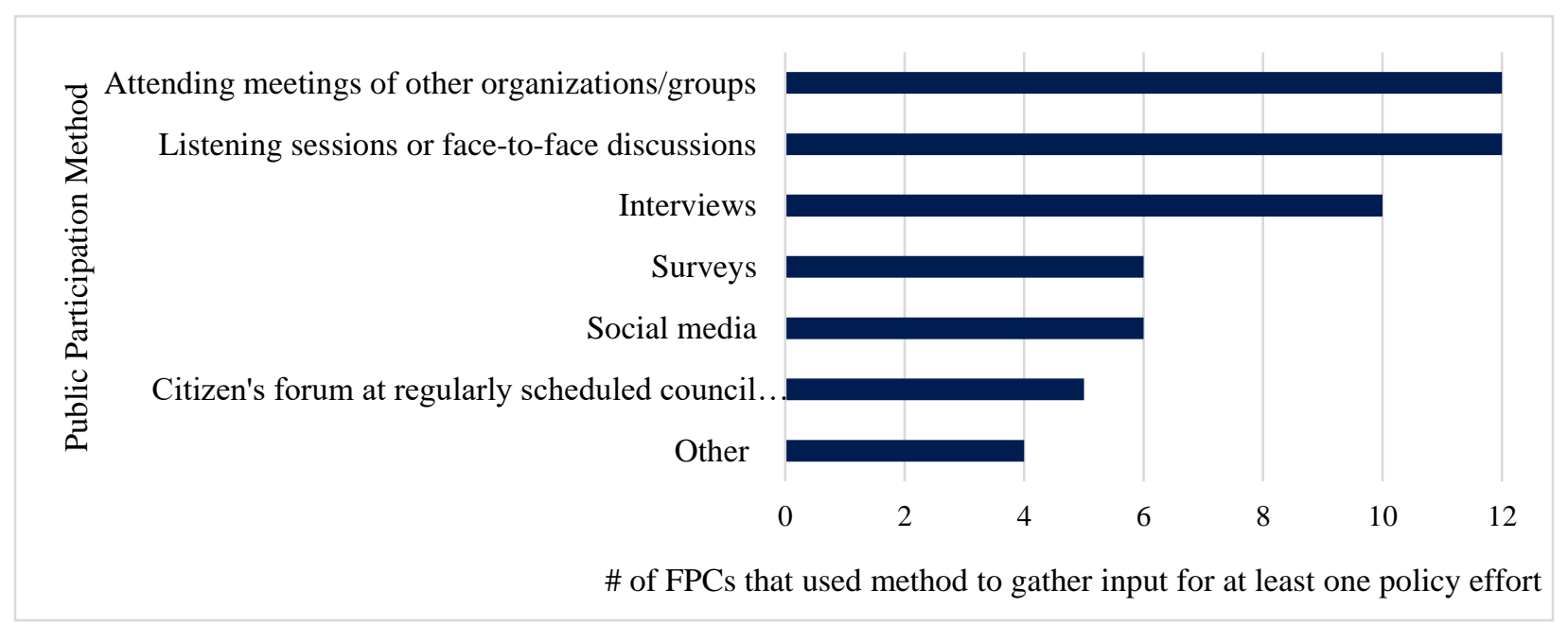


The survey asked respondents to identify the sectors and demographic groups that were engaged in public participation opportunities for each policy effort they identified, which are shown in Table 3. A list of sectors and stakeholders was provided and respondents could also write in others. The results present the number of FPCs reporting they engaged a specific sector or demographic group in at least one policy effort (Figure 6). Where FPCs reported engaging the same sector or demographic group across different policy efforts, the results record this once. Nearly all (11) of the surveyed FPCs report engaging individuals of different genders, varying ages, or a variety of income levels in policy efforts. Most surveyed FPCs (9) report engaging individuals from diverse racial and ethnic backgrounds. The most commonly reported sectors engaged include food access, public health, and schools (K-12). Sectors engaged by fewer surveyed FPCs are colleges and universities, Extension, and fisheries. Other sectors written in by survey respondents included businesses, networks, land trusts, and United Way.

Figure 6. Sectors and stakeholders engaged by surveyed New England FPCs in public participation opportunities.

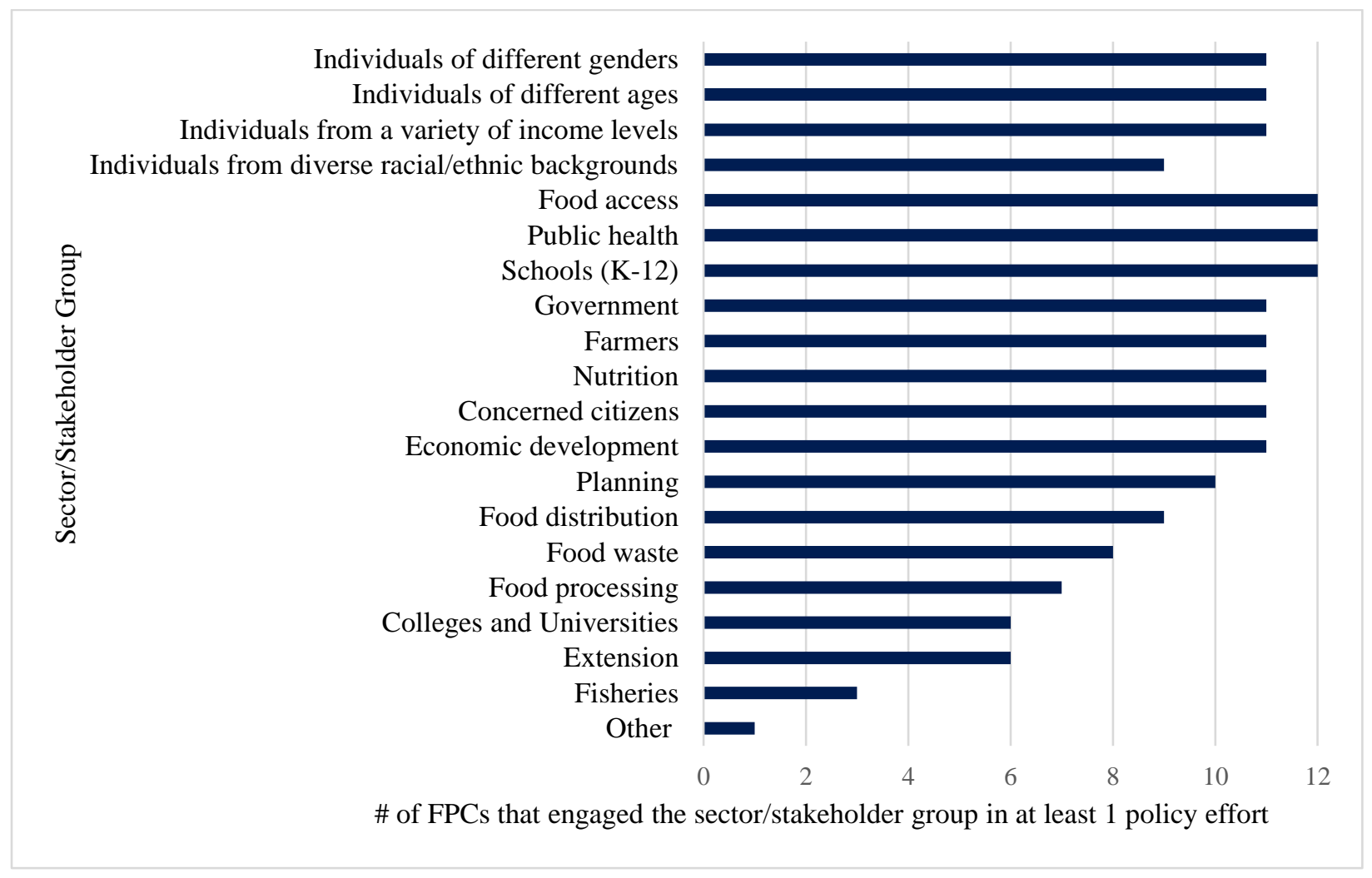

Survey respondents were asked about levels of satisfaction with the public participation opportunities offered by the FPCs as part of the policy efforts. Respondents were asked to rank their own level of satisfaction, their perception of the satisfaction of FPC members, and their perception of the participants' 
satisfaction (Figure 7). While a respondent's perception of the satisfaction of others may not be accurate, these questions about satisfaction were intended to provide information about the quality of the public participation opportunities. Generally, most of the survey respondents report being somewhat or very satisfied with most public participation opportunities. Six respondents were somewhat or very satisfied with the participation opportunities across all of the policy efforts they identified. Two of the respondents reported being somewhat or very satisfied with none of the participation opportunities. Respondents reported being somewhat or very satisfied with 23 out of 33 public participation opportunities, neither satisfied nor dissatisfied with four opportunities, and somewhat dissatisfied with six opportunities.

Figure 7. Survey respondents' satisfaction and perception of FPC members' and participants' satisfaction with public participation opportunities.

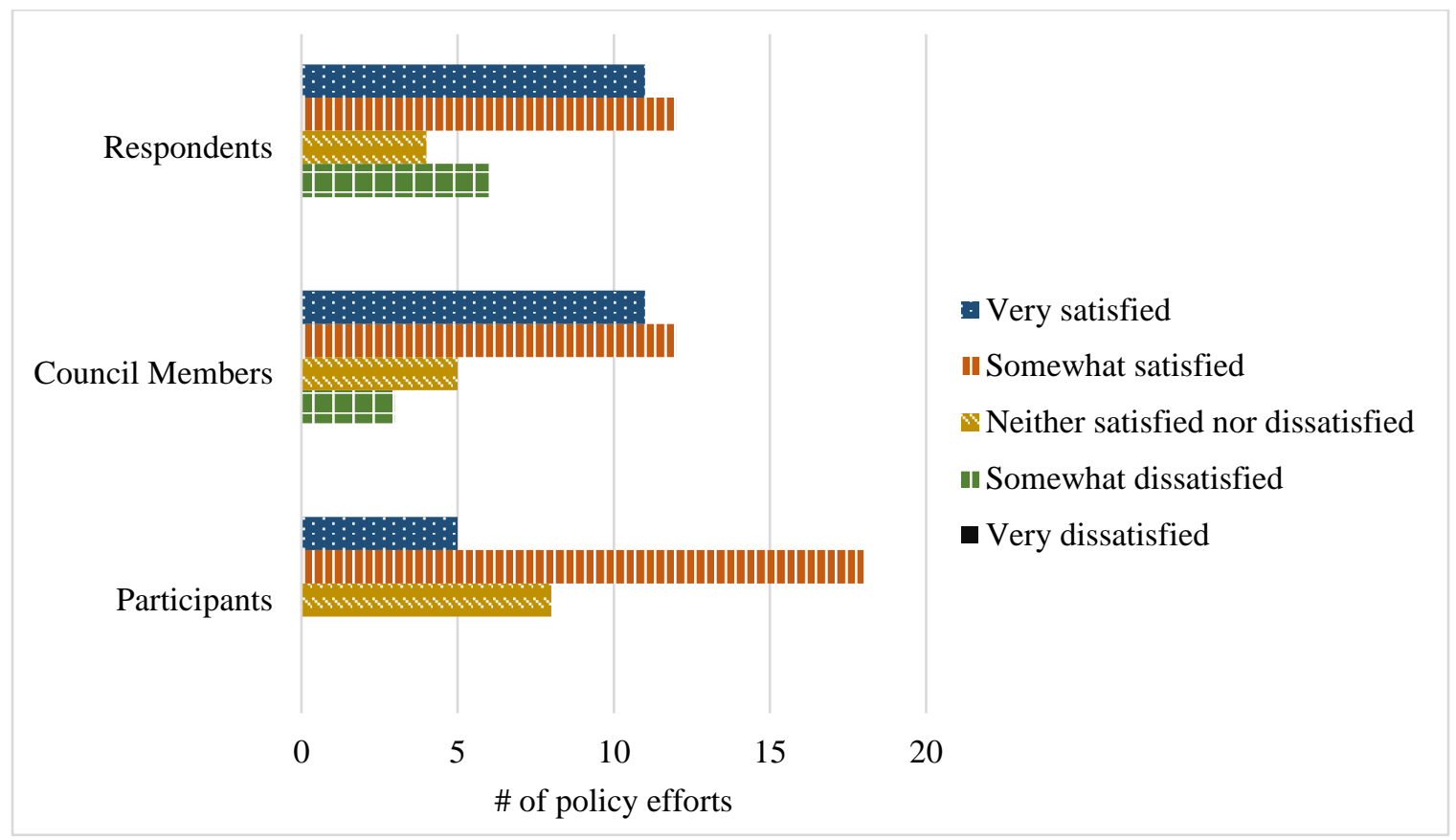

For 20 out of 33 of the policy efforts respondents reported perceiving differences between their own level of satisfaction with public participation opportunities and the level of satisfaction of either the FPC or of the participants. Respondents indicated they perceived participants and FPC members to be less satisfied, as compared to themselves, with participation opportunities in 13 and seven policy efforts, respectively. Respondents indicated they perceived participants and the FPC members to be more satisfied, as compared to themselves, with participation opportunities in six and five policy efforts, respectively. 
Respondents were asked to report whether the input gathered through the public participation opportunities impacted the outcome or decision made. For most policy efforts, 23 out of 33, respondents reported that the input did shape the decision or outcome made by the FPC (Figure 8).

Figure 8. How input gathered through public participation shaped the outcome or decision made by the FPC.

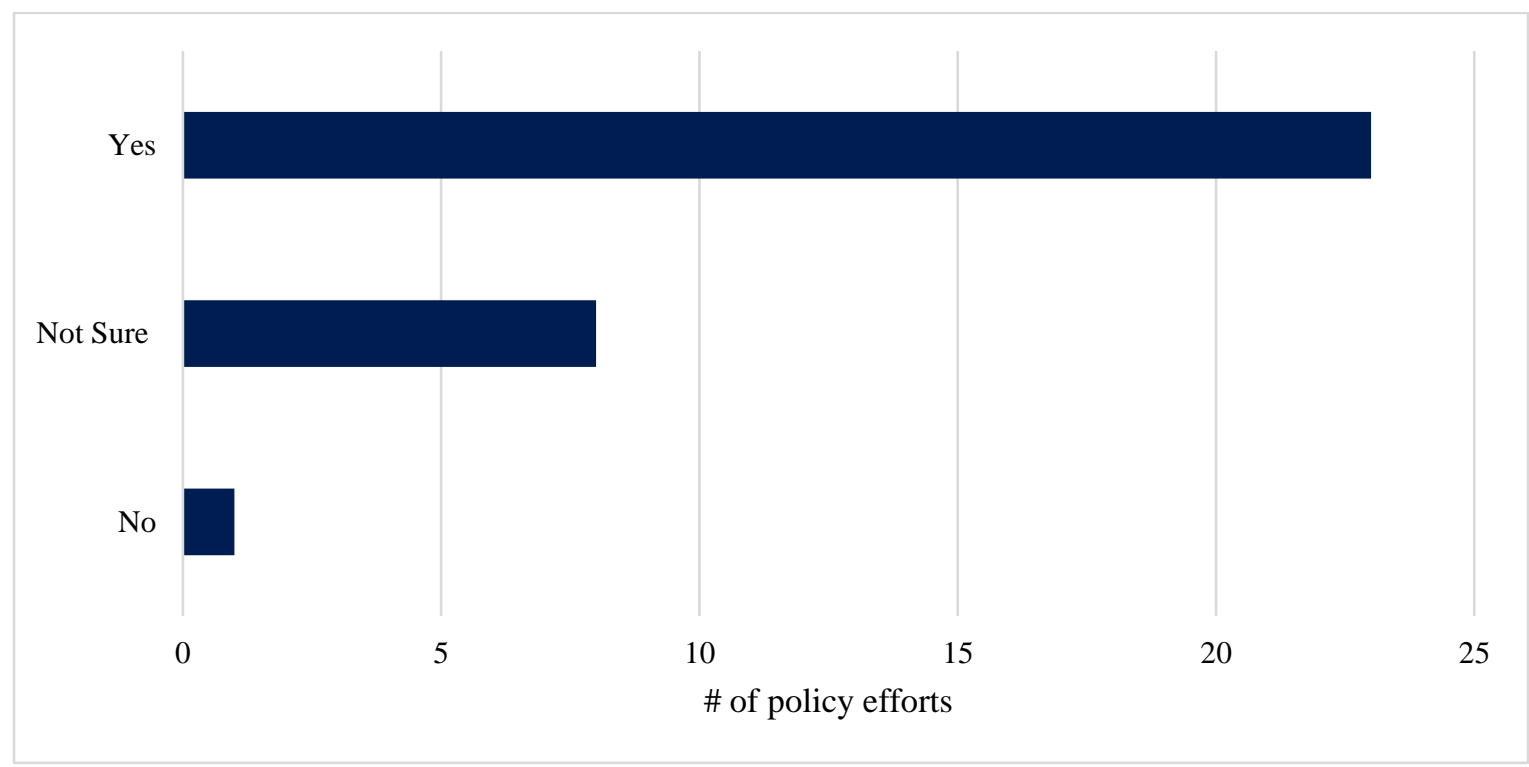

\section{References}

Porter CA, Ashcraft CM. 2020. New England Food Policy Council Survey Instrument. Natural Resources and the Environment Scholarship. doi: https://dx.doi.org/10.34051/c/2020.4

Sussman L, Bassarab K. 2016. Center for a Livable Future Food Policy Council Annual Survey 2016 Responses. 